\title{
THERMODYNAMIC MODELING OF COGENERATION MINI CHP USING AIR CONVERSION OF DIESEL FUEL AND ELECTROCHEMICAL GENERATOR
}

\author{
SERGEI E. SHCHEKLEIN \& ALEXEI M. DUBININ* \\ Ural Federal University named after the first President of Russia B.N. Yeltsin.
}

\begin{abstract}
At present, the production of electrical and heat power uses diesel-generator technology with a limited service life of engines and extremely low efficiency of the expensive fuel used. In this paper, an innovative technology has been considered for the combined electrical and heat power production using the preliminary conversion of diesel fuel into synthesis gas with its subsequent supply to a high temperature electrochemical generator (ECG). Synthesis gas for the operation of the electrochemical generator was produced by air conversion of motor diesel fuels in a catalytic burner reactor. On the basis of heat balances of the burner, ECG and waste-heat boiler-utilizer, electrical efficiency of the solid oxide fuel cells' (SOFC) battery, chemical efficiency of the burner, the temperature at the SOFC anode, the EMF of the planar cell, a portion of hydrogen oxidized at the SOFC anode, specific consumption of diesel fuel for the production of electrical and heat power were calculated. Specific consumption of diesel fuel for the production of electrical and heat power was found to be equal to $114 \mathrm{~g} / \mathrm{kWh}(162 \mathrm{~g} \mathrm{r.f} / \mathrm{kW} \cdot \mathrm{h})$ and $31.7 \mathrm{~kg} / \mathrm{GJ}$ (45.1 kg r.f./GJ, $189 \mathrm{~kg}$ r.f./ Gcal), respectively. Specific fuel consumption is similar to an up-to-date CHP and is significantly lower than the consumption of modern diesel-electric stations of equal power.

Keywords: diesel fuel, electrochemical generator, fuel cell, stoichiometry.
\end{abstract}

\section{INTRODUCTION}

The achievements made over the past several decades in the development of efficient high-temperature solid oxide fuel cells (SOFCs) capable of generating electrical energy from hydrogen contained in the synthesis gas have led to a rapid progress in studies on conversion of natural (methane, coal, petroleum derivatives, etc.) and synthetic (methanol, ethanol, etc.) fuels into synthesis gas followed by its use in SOFCs [1-15]. In [16], more than 220 variants of the SOFC operation with recirculation of anode gases and without it, using methane as a fuel and air as an oxidant were calculated. It was shown that the fuel utilization factor of high-temperature SOFCs can reach from $60 \%$ to $80 \%$, while the choice of the scheme has little effect on the efficiency. In [17], an experimental analysis of a pilot electrochemical generator (ECG) installation based on SOFC with a power of $5 \mathrm{~kW}$ was presented. Natural gas was used as a fuel; air was used as an oxidant. The fuel utilization ratio reached $70 \%$. The installation has worked for more than 7000 hours. In [18], the power plant based on the SOFC battery with recirculation of anode gases was investigated, where methane was used as a fuel and water as an oxidant. The fuel utilization factor reached $60 \%$.

In [19], the performance characteristics of a $5 \mathrm{~kW}$ power plant were investigated. Natural gas was used as a fuel; water was used as an oxidant. The efficiency of the SOFC battery was $73 \%$, the electric efficiency of ECG was $51 \%$. The fuel utilization factor was $52.6 \%$. Calculation studies of the power plant with an electric power of $7.3 \mathrm{~kW}$, operating on coal of the

* ORCID: https://orcid.org/0000-0003-2140-0321 
Borodinsky coal strip mine with water as an oxidant, were presented in [20]. The fuel utilization ratio was $36.4 \%$, the efficiency of the SOFC battery was $36.4 \%$, the electric efficiency of the ECG (gross) was $13.2 \%$, and the chemical efficiency of the gas generator was $36.4 \%$. Specific consumption of reference fuel for the production of electric power was equal to $0.338 \mathrm{~kg}$ r.f. $/ \mathrm{kWh}$, and heat energy supplied to heat networks was $93 \mathrm{~kg}$ r.f./ GJ. Calculation studies were carried out for the ECG, where natural gas was used as a fuel and water was used as an oxidant [21]. The electric power $\left(Q_{\mathrm{e}}\right)$ of the power plant was $5.33 \mathrm{~kW}$. The specific fuel consumption for the generation of electrical power was $0.16 \mathrm{~kg}$ r.f./kWh, and for the heat power, $44.7 \mathrm{~kg}$ r.f./GJ at a fuel utilization ratio equal to 0.71 .

Ref. [22] was devoted to theoretical studies of power parameters of the power plant on the basis of SOFC using solid municipal waste as a fuel and water vapor as an oxidant. The specific consumption of reference fuel for the production of electrical power was $0.153 \mathrm{~kg}$ r.f. $/ \mathrm{kW} \cdot \mathrm{h}$, and heat power, $42.8 \mathrm{~kg}$ r.f./GJ. In order to increase the ECG efficiency, it is recommended in some cases to create hybrid installations using a gas turbine [23]. The electrical efficiency of the power plant was $66 \%$ and that of the SOFC battery was $61.5 \%$.

In this paper, an innovative technology has been considered for the combined electrical and heat power production using the preliminary conversion of diesel fuel into synthesis gas with its subsequent supply to a high temperature electrochemical generator (ECG)

\section{MODELLING OF PHYSICOCHEMICAL PROCESSES IN THE UNITS OF THE MINI-CHPP BASED ON THE CATALYTIC BURNER FOR AIR CONVERSION OF MOTOR DIESEL FUEL AND ELECTROCHEMICAL GENERATOR}

\subsection{Principle and technological model of the process}

In [24] more than 220 variants of the SOFC operation with recirculation of anode gases and without it have been calculated. It has been concluded that the choice of the scheme has little effect on the process efficiency, thus it is advisable to choose the simplest scheme. In the scheme proposed, the anode gases recirculation is not considered. Planar fuel cells with direct flow of fuel and oxidizer are used. Catalysts at the anode and cathode are made of Ni-YSZ and $\left(\mathrm{ZrO}_{2}\right)_{0.9}\left(\mathrm{Sc}_{2} \mathrm{O}_{3}\right)_{0.1}$ is used as an electrolyte (see Fig. 1).

Motor diesel fuel is supplied to the waste-heat boiler (WHB) for heating to boiling and evaporation and enters the catalytic burner in a vaporized form. There also comes the air heated in WHB. When the air flow rate (a dimensionless ratio of actual amount of air fed into the combustion chamber to the theoretically required for burning) $\alpha=0.4$, diesel conversion occurs with the formation of synthesis gas. Then the synthesis gas is cooled from $1284^{\circ} \mathrm{C}$ to $800^{\circ} \mathrm{C}$ in the cooler by the air supplied to the cathode channel.

Synthesis gas is supplied to the anode channel. At the ECG anode, a share of the hydrogen is oxidized by the oxygen of the air supplied to the cathode channel. Products from the anode channel and vitiated air from the cathode channel are fed to the waste-heat boiler, where the remaining hydrogen and carbon monoxide are oxidized. The heat of oxidation is used for heating the primary air and evaporation of the diesel fuel. Then the combustion products from WHB enter the network heater to heat the network water for the needs of hot water supply to heat consumers. Combustion products after the network heater are removed through the stove chimney at a temperature of $120^{\circ} \mathrm{C}$. 


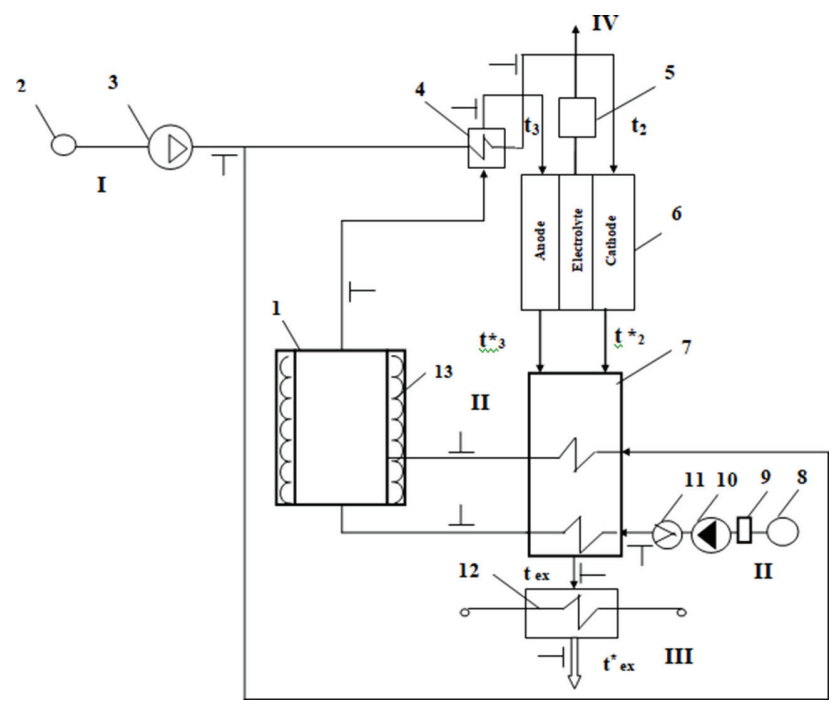

Figure 1: Schematic diagram of mini-CHPP on products of air conversion of motor diesel fuel and electrochemical generator:

1 - catalytic burner; 2 - air pipe; 3 - compressed-air blower; 4 - synthesis gas cooler; 5 - electrical customer; 6 - electrochemical generator based on SOFC; 7 waste-heat boiler-utilizer; 8 - motor diesel fuel manifold; 9 - fuel filter; 10 - fuel pump; 11 - flow-sensing element; 12 - network heater; 13 - thermal insulation. I - air input; II - motor diesel fuel input; III - output of combustion products; IV - electrical power output.

2.2 Modelling of the processes in the technological scheme units

2.2.1 Modelling of the processes in the catalytic burner

It is known [25] that motor diesel fuel contains (in weight \%) carbon - 87, hydrogen - 12.6 and oxygen -0.5 . For further calculations let us define the diesel fuel composition in atomic fractions of the elements contained in it [25]. It contains $n=87 / 12=8$ of carbon, $m=2 n+2$ $=18$ of hydrogen and $l=0.5 / 16=0.03$ of oxygen. Since the oxygen content is low, it can be neglected in further calculations. In this case, the diesel fuel formula can be written as $\mathrm{C}_{8} \mathrm{H}_{18}$. The minimum coefficient of air consumption at which the emission of soot in the products of conversion is thermodynamically impossible:

$$
\alpha=(n-1) /(2 n+0.5 m-1)
$$

We take the coefficient of air flow $\alpha>\alpha_{c}(\alpha=0.4)$. When, in the reaction volume of the catalytic burner, the air flow rate is equal to 0.4 , synthesis gas is produced according to the stoichiometric equation:

$$
\begin{gathered}
\mathrm{C}_{8} \mathrm{H}_{18}+5\left(\mathrm{O}_{2}+3.76 \mathrm{~N}_{2}\right)=7.938 \mathrm{H}_{2}+7.056 \mathrm{CO}+0.089 \mathrm{CO}_{2}+ \\
1.062 \mathrm{H}_{2} \mathrm{O}+0.994 \mathrm{CO}_{2}+18.8 \mathrm{~N}_{2}
\end{gathered}
$$

The composition of the synthesis gas produced (in volume \%): $\mathrm{H}_{2}-22.1 ; \mathrm{CO}-19.68$; $\mathrm{H}_{2} \mathrm{O}-2.96 ; \mathrm{CO}_{2}-2.77 ; \mathrm{N}_{2}-52.49$. 
The heat of combustion of the synthesis gas is determined according to the stoichiometric equation of complete oxidation of synthesis gas:

$$
\begin{gathered}
7.938 \mathrm{H}_{2}+7.056 \mathrm{CO}+1.062 \mathrm{H}_{2} \mathrm{O}+0.994 \mathrm{CO}_{2}+18.8 \mathrm{~N}_{2}+7.497 \mathrm{O}_{2}+28.18 \mathrm{~N}_{2}= \\
8 \mathrm{CO}_{2}+9 \mathrm{H}_{2} \mathrm{O}+47 \mathrm{~N}_{2} \\
q_{\text {chem }}=-4872 \mathrm{~kJ} /(\mathrm{kg} \text { of synthesis gas })
\end{gathered}
$$

Complete combustion of the diesel fuel at the air flow rate factor $\alpha$ equal to 1 is described by the stoichiometric equation:

$$
\mathrm{C}_{8} \mathrm{H}_{18}+12.5\left(\mathrm{O}_{2}+3.76 \mathrm{~N}_{2}\right)=8 \mathrm{CO}_{2}+9 \mathrm{H}_{2} \mathrm{O}+47 \mathrm{~N}
$$

The number of kilomoles of air at the flow rate factor $\alpha=0.4$ is equal to $12.5 \cdot 0.4=5$ (see eqn (2)).

The combustion value of the diesel fuel is $Q^{\mathrm{P}}{ }_{\text {low }}=41800 \mathrm{~kJ} /(\mathrm{kg}$ of diesel fuel). The boiling temperature is $\mathrm{t}_{1}=380^{\circ} \mathrm{C}$.

According to preliminary calculations for the ECG to achieve the electrical power level of $10 \mathrm{~kW}$ the synthesis gas required with the heat of combustion $q_{\text {chem }}=4872 \mathrm{~kJ} /(\mathrm{kg}$ of synthesis gas) is

$$
B_{s g}=Q_{\mathrm{e}} /\left(q_{\text {chem }} \eta^{*}\right)
$$

where the coefficient of efficiencyCE) of the ECG is tentatively assumed to be equal to according to the data presented in [26].

For the production of $B_{s g}$ it is necessary to introduce into the burner the following amount of diesel fuel, $\mathrm{kg} / \mathrm{s}$

$$
G_{d f}=B_{s g} \cdot 114 / 800
$$

and primary air, $\mathrm{kg} / \mathrm{s}$

$$
G_{\text {air } 1}=G_{d f} \cdot 686.4 / 114
$$

Heat balance equation for the catalytic burner:

$$
Q_{\text {low }}^{\mathrm{p}} \cdot \alpha \cdot 114 / 800\left(1-q_{3}-q_{5}\right)+q_{a i r 1}+q_{v}=C_{c} t
$$

On the left side of eqn (8) is the heat input from incomplete combustion with taking into account losses with chemical underburning and external heat losses through thermal insulation $Q_{\text {low }}^{\mathrm{p}} \cdot a \cdot 114 / 800\left(1-q_{3}-q_{5}\right)$, from primary air heated in WHB $-q_{\text {air } 1}$ and steam $-q_{v}$; on the right side - heat consumption for heating the synthesis gas conversion products, $q_{3}=0.05$, $q_{5}=0.3$.

The coefficient $114 / 800$, which converts $Q_{l o w}^{\mathrm{p}} \mathrm{KJ} /(\mathrm{kg}$ of diesel fuel $)$ to $\mathrm{kJ} /(\mathrm{kg}$ of synthesis gas), has been found from eqn (2).

The heat introduced by primary air into the burner heated to $t_{1}=380^{\circ} \mathrm{C}$ :

$q_{\text {air } 1}=C_{\text {air }} \mathrm{t}_{1} / 800=6861.056380 / 800=344 \mathrm{~kJ} /(\mathrm{kg}$ of synthesis gas $)$.

The heat introduced by vaporized diesel fuel:

$q_{\mathrm{v}}=C_{\mathrm{v}} t_{1} / 800=3.5380114 / 380189 \mathrm{~kJ} /(\mathrm{kg}$ of synthesis gas $)$, where $C_{\text {air }}, C_{\mathrm{v}}$, true specific isobaric heat capacities of air and vaporized diesel fuel at $380{ }^{\circ} \mathrm{C}$, are equal to 1.056 and $3.5 \mathrm{~kJ} /(\mathrm{Kkg})$, respectively.

True specific isobaric heat capacity of synthesis gas $C_{s g}=1.62 \mathrm{~kJ} /(\kappa \mathrm{kg}$ of synthesis gas $)$. 
From the heat balance equation, the temperature in the catalytic burner can be determined as:

$$
t=\left[Q_{l o w}^{\mathrm{p}} a\left(1-q_{3}-q_{5}\right) 114 / 800+q_{a i r 1}+q_{v}\right] / C_{s g}
$$

Chemical efficiency of the catalytic burner can be written as:

$$
\eta_{\text {chem }}=B_{\text {sg }} \cdot q_{\text {chem }} /\left(G_{d t} \cdot Q_{\text {low }}^{\mathrm{p}}\right)
$$

\subsubsection{Synthesis gas in the electrochemical generator: physicochemical processes}

Synthesis gas cooled in the heat exchanger (4) down to $\mathrm{t}_{3}=800^{\circ} \mathrm{C}$ is fed to the anode channel, while the air heated up to $t_{2}=620^{\circ} \mathrm{C}$ in the heat exchanger (4) is fed to the cathode channel of the ECG. According to [27], contribution to the EMF value from the $\mathrm{CO}$ oxidation reaction at the SOFC anode is less than $1 \%$ of that from hydrogen oxidation; therefore, it is neglected in the calculations, and assumed that only hydrogen is oxidized at the SOFC anode.

The water-gas reaction $\mathrm{CO}+\mathrm{H}_{2} \mathrm{O}_{<-}{ }_{->} \mathrm{CO}_{2}+\mathrm{H}_{2}$ cannot be a donor of hydrogen, since this reaction proceeds only on the iron-chromium catalyst [27], which is absent in the anode channel.

At the SOFC anode, the oxidation of hydrogen from the synthesis gas by oxygen coming from the electrolyte is described by a stoichiometric equation assuming all the hydrogen to be completely oxidized:

$$
\begin{gathered}
7.938 \mathrm{H}_{2}+7.056 \mathrm{CO}+1.062 \mathrm{H}_{2} \mathrm{O}+0.994 \mathrm{CO}_{2}+18.8 \mathrm{~N}_{2}+3.969 \mathrm{O}_{2} \\
=9 \mathrm{H}_{2} \mathrm{O}+7.056 \mathrm{CO}+0.994 \mathrm{CO}_{2}+18.8 \mathrm{~N}_{2}
\end{gathered}
$$

The exothermic effect of reaction (11) under standard conditions $\Delta H_{1}^{0}$ is equal to $2400 \mathrm{~kJ} /$ ( $\mathrm{kg}$ of synthesis gas), while the change of Gibbs free energy for the reaction under standard conditions $\Delta G^{0}=-2863.59 \mathrm{~kJ} /(\mathrm{kg}$ of synthesis gas $), \Delta S^{0}=0.44 \mathrm{~kJ} /(\mathrm{kg} \mathrm{K})$.

According to [28], the temperature of the hydrogen oxidation products at the anode is

$$
T_{3}{ }^{*}=\left(\Delta H_{1}^{0}-\Delta G^{0}\right) / \Delta S^{0}
$$

The temperature level is in accordance with [19]. The EMF of a planar cell at the temperature of $T_{3}{ }^{*}$ is equal to

$$
E_{\mathrm{e}}=\Delta G /(2 F)
$$

where $F=9.64810^{4} \mathrm{C} / \mathrm{mol}$ is the Faraday constant; $\Delta G \mathrm{~kJ} /(\mathrm{kmol}$ of water) is determined at $T_{3}{ }^{*}$.

Fuel cells usually operate under isobaric-isothermal conditions. The work in the isobaricisothermal process is equal to the negative change in of the free Gibbs energy [28], and the electrical power is equal to the negative change in the free Gibbs energy $\Delta G, \mathrm{~kJ} /(\mathrm{kg}$ of synthesis gas) at $T_{\mathrm{e}}^{*}$, multiplied by the synthesis gas consumption $B_{\mathrm{sg}}, \mathrm{kg} / \mathrm{s}$ :

$$
Q_{\mathrm{e}}=B_{\mathrm{sg}} \Delta G
$$

On the other hand, the electrical power is [19]:

$$
Q_{\mathrm{e}}=B_{\mathrm{sg}} q_{\text {chem }} \eta
$$

Equating these expressions, the electrical efficiency of the SOFC battery is determined and then compared with [26, 29]. 
Heat balance equation for the electrochemical unit

It is assumed that the SOFC battery is ideally insulated, the chemical underburning is equal to zero.

The equation for the balance of incoming and outgoing energy flows has the form

$$
B_{s g} \varphi_{T} \Delta \mathrm{H}_{1}^{0}+B_{s g} C_{s g} t_{3}+G_{\text {air }} \mathbf{C}_{\text {air }} t_{2}=Q_{e}+C_{s g}^{*} B_{s g}^{*} t_{3}^{*}+C_{\text {air }}^{*} G_{\text {air }}^{*} t_{2}^{*}
$$

where:

$B_{\text {sg }} \varphi_{\mathrm{T}} \Delta \mathrm{H}^{0}{ }_{1}$ - power, selected the oxidation of hydrogen at the anode SOFC,

$B_{\text {sg }} C_{\text {sg }} t_{3}$ - power paid synthesis-gas emerging from the cooler (see Fig. 1),

$G_{\text {air }} C_{\text {air }} t_{2}$ - power, the air coming from the boiler-heat exchanger,

$Q_{\mathrm{e}}$ - electrical power removed from the ECG,

$B_{\mathrm{sg}}^{*} C_{\mathrm{sg}}^{*} t^{*}$ - power assigned to partially oxidized synthesis-gas, partly oxidized, outgoing from anode channel,

$G_{\text {air }}^{*} C_{\text {air }}^{*} t_{2}^{*}$ - power, assigned to the air outgoing from the cathode canal,

$\varphi_{\mathrm{T}}$ - a portion of hydrogen oxidized at the anode.

The temperature $t_{3}$ at the inlet of the synthesis gas to the anode channel is assumed to be $800^{\circ} \mathrm{C}$. The specific true isobaric heat capacity of the synthesis gas at $800^{\circ} \mathrm{C}$ is determined from eqn (2) as $C_{\mathrm{sg}}=1.5 \mathrm{~kJ} /(\mathrm{K} \mathrm{kg}$ of synthesis gas).

The air temperature at the outlet from the synthesis gas cooler (at the inlet to the cathode channel) $t_{2}$ is determined from the heat balance equation of the synthesis gas cooler and equal to $620^{\circ} \mathrm{C}$. The specific true isobaric heat capacity of the air at the temperature of $620^{\circ} \mathrm{C} C_{\text {air }}=$ $1.115 \mathrm{~kJ} / \mathrm{K} \mathrm{kg}$ (found from eqn (3)). The temperature $t_{3}^{*}$ is equal to $780^{\circ} \mathrm{C}$ (it was defined earlier, see Form. (12)).

The specific true isobaric heat capacity of the oxidized synthesis gas at the outlet from the anode at $780^{\circ} \mathrm{C} C_{s g}^{*}=1.161 \mathrm{~kJ} /(\mathrm{K} \cdot \mathrm{kg}$ of synthesis gas $)$ is determined from eqn (11). The air temperature at the outlet from the cathode channel is assumed to be by $100^{\circ} \mathrm{C}$ below, i.e. $780-100=680^{\circ} \mathrm{C}$.

The specific true isobaric heat capacity of the air depleted in oxygen at the outlet from the cathode channel is $(7.497-3.969) \mathrm{O}_{2}+28.18 \mathrm{~N}_{2}$ at $680^{\circ} \mathrm{C}, C_{\text {air }}^{*}=1.166 \mathrm{~kJ} / \mathrm{Kkg}$.

The air flow rate into the cathode channel necessary for the complete oxidation of synthesis gas can be calculated using eqn (3) as:

$$
G_{\text {air }}=(240+789) B_{s g} / 800=1.285 \cdot 5.32 \cdot 10^{-3}=6.84 \cdot 10^{-3} \mathrm{~kg} / \mathrm{s} .
$$

The flow rate of vitiated air at the outlet of the cathode channel can be determined from eqns (3) and (11):

$$
G_{\text {air }}^{*}=G_{\text {air }}-3.969 \cdot 32 \cdot B_{\text {sg }} / 800=(6.84-0.158 \cdot 5.32) \cdot 10^{-3}=5.99 \cdot 10^{-3} \mathrm{~kg} / \mathrm{s}
$$

The consumption of synthesis gas at the outlet of the anode channel can also be determined from eqn (11):

$$
B_{s g}^{*}=(9 \cdot 18+7.656 \cdot 28+0.994 \cdot 44+18.8 \cdot 28) B_{s g} / 800=1.16 \cdot 5.32 \cdot 10^{-3}=6.17 \cdot 10^{-3} \mathrm{~kg} / \mathrm{s}
$$

The materials balance at the ECG input and output has converged.

From the heat balance eqn (16), a portion of hydrogen oxidized at the anode can be calculated 
(all the parameters included in the heat balance equation are presented in Table 1):

$$
\varphi_{T}=\left(Q_{e}+C_{s g}^{*} B_{s g}^{*} t_{3}^{*}+C_{a i r}^{*} G_{a i r}^{*} t_{2}^{*}-B_{s g} C_{s g} t_{3}-G_{a i r} C_{a i r} t_{2}\right) /\left(B_{s g} \Delta H_{1}^{0}\right)
$$

Substitution in the last equation of the parameters presented in Table 1 gives the value of $\varphi_{T}$, which agrees with the data of [30].

2.2.3 Modelling of the processes in the waste-heat boiler - utilizer: physicochemical processes

The rest hydrogen, not oxidized at the anode, is oxidized is WHB with power release:

$$
\left(1-\varphi_{T}\right) B_{s g} \Delta H_{1}^{0}
$$

Carbon oxide, coming from the anode channel, is oxidized by oxygen-depleted air (7.4973.969) $\mathrm{O}_{2}+28.18 \mathrm{~N}_{2}$, outgoing from the cathode channel, according to the stoichiometric equation:

$9 \mathrm{H}_{2} \mathrm{O}+7.056 \mathrm{CO}+0.994 \mathrm{CO}_{2}+18.82 \mathrm{~N}_{2}+3.528 \mathrm{O}_{2}+28.18 \mathrm{~N}_{2}=9 \mathrm{H}_{2} \mathrm{O}+8 \mathrm{CO}_{2}+47 \mathrm{~N}_{2}$

The exothermic effect of reaction (18) is $\mathrm{kJ} /(\mathrm{kg}$ of synthesis gas).

Power balance for the waste-heat boiler-utilizer.

The equation for the balance for the waste-heat boiler-utilizer has the form

$$
\begin{aligned}
& \left(1-q_{3}-q_{5}\right)\left(C_{s g}^{*} B_{s g}^{*} t_{3}^{*}+C_{a i r}^{*} G_{a i r}^{*} t_{2}^{*}+\left(1-\varphi_{T}\right) B_{s g} \Delta H_{1}^{0}+\Delta H_{2}^{0} B_{s g}\right) \\
& =G_{\text {air } 1} C_{a i r}\left(t_{1}-t_{\text {air }}\right)+G_{d f}\left[C_{d f}\left(t_{1}-t_{d f}\right)+r_{d f}\right]+G_{e x} C_{e x} t_{e x}
\end{aligned}
$$

Table 1: Values of the parameters in eqn (17).

\begin{tabular}{ccc}
\hline Value & Unit & Designation \\
\hline $5.32 \cdot 10^{-3}$ & $\mathrm{~kg} / \mathrm{s}$ & $B_{\mathrm{sg}}$ \\
$6.17 \cdot 10^{-3}$ & $\mathrm{~kg} / \mathrm{s}$ & $B_{\mathrm{sg}}^{*}$ \\
1.5 & $\mathrm{~kJ} / \mathrm{K} \cdot \mathrm{kg}$ & $C_{\mathrm{sg}}$ \\
1.161 & $\mathrm{~kJ} / \mathrm{K} \cdot \mathrm{kg}$ & $C_{\mathrm{sg}}^{*}$ \\
1.166 & $\mathrm{~kJ} / \mathrm{K} \cdot \mathrm{kg}$ & $C_{\text {air }}^{*}$ \\
1.115 & $\mathrm{~kJ} / \mathrm{K} \cdot \mathrm{kg}$ & $C_{\text {air }}$ \\
$6.84 \cdot 10^{-3}$ & $\mathrm{~kg} / \mathrm{s}$ & $G_{\text {air }}$ \\
$5.99 \cdot 10^{-3}$ & $\mathrm{~kg} / \mathrm{s}$ & $G_{\text {air }}^{*}$ \\
620 & ${ }^{\circ} \mathrm{C}$ & $t_{2}$ \\
680 & ${ }^{\circ} \mathrm{C}$ & $t_{2}^{*}$ \\
800 & ${ }^{\circ} \mathrm{C}$ & $t_{3}$ \\
780 & ${ }^{\circ} \mathrm{C}$ & $t_{3}^{*}$ \\
2400 & $\mathrm{~kJ} / \mathrm{K} \cdot \mathrm{kg}$ & $\Delta H_{1}^{0}$ \\
10 & $\mathrm{~kW}$ & $\mathrm{Q}_{\mathrm{e}}$ \\
\hline
\end{tabular}


Where:

$C_{s g}^{*} B_{s g}^{*} t_{3}^{*}-$ the power coming with products from the anode channel,

$C_{\text {air }}^{*} B_{\text {air }}^{*} t_{2}^{*}$ the power coming with air from the cathode channel,

$\left(1-\varphi_{T}\right) \cdot B_{s g} \Delta \mathrm{H}_{1}^{0}$-the power coming released from the oxidizing the rest hydrogen,

$\Delta \mathrm{H}_{2}^{0} B_{s g}$ - the power non-oxidized at the anode and carbon oxide, with primary air,

$G_{\text {airl }} C_{\text {air }} t_{\text {air }}$ - the power inflowing to the catalytic burner,

$G_{\mathrm{df}} C_{\mathrm{df}} t_{\mathrm{df}}$ the power with diesel fuel,

$G_{\text {airl }} C_{\text {air }} t_{1}$ - the power is spent on heating the primary air,

$\left.G_{\mathrm{df}[} \mathrm{C}_{d f}\left(t_{1}-t_{d f}\right)+r_{\mathrm{df}}\right]$-heating to boiling and evaporating the diesel fuel,

$G_{e x} C_{e x} t_{e x}$-heating exhausted combustion products from the boiler-utilizer, $\mathrm{q}_{3}=0.03, \mathrm{q}_{5}=0.242$.

From the heat balance equation, the temperature of the gases outgoing from the WHB can be determined (all the parameters in eqn (19) are presented in Table 2).

The specific isobaric heat capacity of diesel fuel is $C_{\mathrm{df}}=1.84 \mathrm{~kJ} / \mathrm{K} \cdot \mathrm{kg}$.

$$
G_{e x}=B_{s g}^{*}+G_{a i r}^{*}=B_{s g}+G_{a i r}=(6.17+5.99) 10^{-3}=(5.32+6.84) 10^{-3}=12.16 \cdot 10^{-3} \mathrm{~kg} / \mathrm{s}
$$

Table 2: Values of the parameters in eqn (20).

\begin{tabular}{ccc}
\hline Value & Unit & Designation \\
\hline $5.32 \cdot 10^{-3}$ & $\mathrm{~kg} / \mathrm{s}$ & $B_{\mathrm{sg}}$ \\
$6.17 \cdot 10^{-3}$ & $\mathrm{~kg} / \mathrm{s}$ & $B_{\mathrm{sg}}^{*}$ \\
1.161 & $\mathrm{~kJ} / \mathrm{K} \cdot \mathrm{kg}$ & $C_{\mathrm{sg}}^{*}$ \\
1.166 & $\mathrm{~kJ} / \mathrm{K} \cdot \mathrm{kg}$ & $C_{\text {air }}^{*}$ \\
1.056 & $\mathrm{~kJ} / \mathrm{K} \cdot \mathrm{kg}$ & $C_{\text {air }}$ \\
1.38 & $\mathrm{~kJ} / \mathrm{K} \cdot \mathrm{kg}$ & $C_{\mathrm{ex}}$ \\
$4.56 \cdot 10^{-3}$ & $\mathrm{~kg} / \mathrm{s}$ & $G_{\text {air }}$ \\
$5.99 \cdot 10^{-3}$ & $\mathrm{~kg} / \mathrm{s}$ & $G_{\text {air }}^{*}$ \\
1.84 & $\mathrm{~kJ} / \mathrm{K} \cdot \mathrm{kg}$ & $C_{\mathrm{df}}$ \\
$0.758 \cdot 10^{-3}$ & $\mathrm{~kg} / \mathrm{s}$ & $G_{\mathrm{df}}$ \\
$12.16 \cdot 10^{-3}$ & $\mathrm{~kg} / \mathrm{s}$ & $G_{\mathrm{ex}}$ \\
380 & ${ }^{\circ} \mathrm{C}$ & $t_{1}$ \\
20 & ${ }^{\circ} \mathrm{C}$ & $t_{\text {air }}$ \\
680 & ${ }^{\circ} \mathrm{C}$ & $t_{2}^{*}$ \\
780 & ${ }^{\circ} \mathrm{C}$ & $t_{3}^{*}$ \\
20 & ${ }^{\circ} \mathrm{C}$ & $t_{\mathrm{df}}$ \\
2400 & $\mathrm{kJJ} / \mathrm{kg}$ & $\Delta H_{1}^{0}$ \\
2472 & $\mathrm{~kJ} / \mathrm{kg} / \mathrm{ung}$ & $\Delta H_{2}^{0}$ \\
0.745 & & $\varphi_{\mathrm{T}}$ \\
644 & $\mathrm{r}_{d f}$ \\
\hline
\end{tabular}


$r_{\mathrm{df}}-$ the heat of evaporation of diesel fuel kJ.kg.

$$
\begin{aligned}
t_{e x}= & \left\{\left(1-q_{3}-q_{5}\right)\left(C_{s g}^{*} B_{s g}^{*} t_{3}^{*}+C_{\text {air }}^{*} G_{\text {air }}^{*} t_{2}^{*}+\left(1-\varphi_{T}\right) B_{s g} \Delta H_{1}^{0}+\Delta H_{2}^{0} B_{s g}\right)\right. \\
& \left.-G_{\text {air } 1} C_{\text {air }}\left(t_{1}-t_{\text {air }}\right)-G_{d f}\left[C_{d f}\left(t_{1}-t_{d f}\right)+r_{d f}\right]\right\} /\left(G_{e x} C_{e x}\right)
\end{aligned}
$$

The results of the calculations are summarized in Table 3.

Power supplied to the network heater to heat the network water for hot water needs of heat consumers can be calculated as

$$
Q_{n h}=G_{e x} C_{e x}\left(t_{e x}-t_{e x}^{*}\right)
$$

where $t_{e x}^{*}$ is the temperature after the network heater, which is assumed to be equal to $120^{\circ} \mathrm{C}$.

Coefficient of fuel utilization in the mini-CHPP can be calculated as follows:

$$
\eta_{u t}=\left(Q_{\mathrm{e}}+Q_{n h}\right) /\left(Q_{l o w}^{p} G_{d f}\right)
$$

\begin{tabular}{|c|c|c|c|c|}
\hline Parameter designation & Designation & Dimension & $\begin{array}{c}\text { Eq. } \\
\text { number }\end{array}$ & Value \\
\hline $\begin{array}{l}\text { Air flow rate at the sooting formation } \\
\text { point }\end{array}$ & $\alpha_{c}$ & dim. less & (1) & 0.32 \\
\hline $\begin{array}{l}\text { Synthesis gas flow rate (specific con- } \\
\text { sumption) }\end{array}$ & $B_{s g}$ & $\mathrm{~kg} / \mathrm{s}$ & $(5)$ & $5.32 \cdot 10^{-3}$ \\
\hline $\begin{array}{l}\text { Diesel fuel flow rate } \\
\text { (specific consumption) }\end{array}$ & $G_{d f}$ & $\mathrm{~kg} / \mathrm{s}$ & (6) & $0.758 \cdot 10^{-3}$ \\
\hline Primary air flow rate to the burner & $G_{\text {air } 1}$ & $\mathrm{~kg} / \mathrm{s}$ & (7) & $4.56 \cdot 10^{-3}$ \\
\hline Burner temperature & $t$ & ${ }^{\circ} \mathrm{C}$ & (9) & 1284 \\
\hline Burner chemical efficiency & $\eta_{\text {chem }}$ & $\%$ & (10) & 81.7 \\
\hline Temperature at the SOFC anode & $\begin{array}{l}T_{3}^{*} \\
t_{3}^{*}\end{array}$ & $\begin{array}{l}\mathrm{K} \\
{ }^{\mathrm{o}} \mathrm{C}\end{array}$ & (12) & $\begin{array}{l}1053 \\
(780)\end{array}$ \\
\hline EMF of the single planar cell & $E_{e}$ & $\mathrm{~V}$ & (13) & 0.985 \\
\hline ECG electrical power & $Q_{e}$ & $\mathrm{~kW}$ & (14) & 10 \\
\hline ECG electrical efficiency (gross) & $\eta$ & $(\%)$ & $(15)$ & 0.386 \\
\hline $\begin{array}{l}\text { Volume fraction of hydrogen oxidized } \\
\text { at the anode }\end{array}$ & $\varphi_{\mathrm{T}}$ & $\%$ & (17) & 74.5 \\
\hline $\begin{array}{l}\text { Temperature of gases outgoing from } \\
\text { the boiler-utilizer }\end{array}$ & $t_{e x}$ & ${ }^{\circ} \mathrm{C}$ & $(20)$ & 950 \\
\hline Network water heater capacity & $Q_{\mathrm{nh}}$ & $\mathrm{kW}$ & $(21)$ & 13.9 \\
\hline Coefficient of fuel utilization in CHPP & $\eta_{\mathrm{ut}}$ & dim. less & $(22)$ & 0.754 \\
\hline
\end{tabular}

Table 3: Results of calculations for the mini-CHPP typical operation. 


\begin{tabular}{lcccc}
\hline $\begin{array}{l}\text { Absolute consumption of diesel fuel } \\
\text { for the production of electrical power }\end{array}$ & $G_{\mathrm{e}}$ & $\mathrm{kg} / \mathrm{h}$ & $(23)$ & 1.05 \\
$\begin{array}{l}\text { Specific consumption of diesel fuel } \\
\text { for the production of electrical power }\end{array}$ & $b_{\mathrm{e}}$ & $\mathrm{kg} / \mathrm{kW} \cdot \mathrm{h}$ & $(24)$ & 0.114 \\
$\begin{array}{l}\text { Absolute consumption of diesel fuel } \\
\text { for the production of heat power }\end{array}$ & $G_{\mathrm{T}}$ & $\mathrm{kg} / \mathrm{h}$ & $(25)$ & 1.587 \\
$\begin{array}{l}\text { Specific consumption of diesel fuel } \\
\text { for the production of heat power }\end{array}$ & $b_{\mathrm{T}}$ & $\mathrm{kg} / \mathrm{GJ}$ & $(26)$ & 31.7 \\
$\begin{array}{l}\text { Difference in diesel fuel flow rates } \\
\text { supplied to ECG and used beneficially } \\
\text { in power plant }\end{array}$ & $\Delta G_{\mathrm{df}}$ & $\mathrm{kg} / \mathrm{s}$ & $(27)$ & 0 \\
$\begin{array}{l}\text { Reagents input flow rate } \\
\text { Reagents output flow rate }\end{array}$ & $\mathrm{G}_{\text {in }}$ & $\mathrm{kg} / \mathrm{s}$ & $(28)$ & $12.16 \cdot 10^{-3}$ \\
$\begin{array}{l}\text { Flow rate imbalance } \\
\text { Power input }\end{array}$ & $\mathrm{G}_{\text {out }}$ & $\mathrm{kg} / \mathrm{s}$ & $(29)$ & $12.16 \cdot 10^{-3}$ \\
Power output & $\Delta G$ & $\mathrm{~kg} / \mathrm{s}$ & $(30)$ & 0 \\
Power imbalance & $\mathrm{Q}_{\text {in }}$ & $\mathrm{kg} / \mathrm{s}$ & $(31)$ & 25.94 \\
\hline
\end{tabular}

\section{ENERGY PERFORMANCE OF THE MINI-CHPP}

3.1 Differentiation of the diesel fuel consumption between the production of electrical and heat energy and the specific fuel consumption

Below are calculated in line with the methodology [31], absolute and specific consumption of diesel fuel in cogeneration of electricity and heat production.

Absolute consumption of diesel fuel for the production of electrical power, $\mathrm{kg} / \mathrm{h}$

$$
G_{e}=Q_{\mathrm{e}} \cdot 1 \cdot 3600 /\left(Q_{\text {low }}^{p} \eta_{u t}\right)
$$

Specific consumption of diesel fuel for the production of electrical power, $\mathrm{kg} / \mathrm{kW} \cdot \mathrm{h}$

$$
b_{e}=G_{e} /\left(Q_{e} \cdot 1\right) .
$$

Absolute consumption of diesel fuel for the production of heat power, $\mathrm{kg} / \mathrm{h}$

$$
G_{T}=Q_{n h} \cdot 1 \cdot 3600 /\left(\mathrm{Q}_{\text {low }}^{p} \eta_{u t}\right)
$$

Specific consumption of diesel fuel for the production of heat power, $\mathrm{kg} / \mathrm{kW} \cdot \mathrm{h}$

$$
b_{T}=G_{T} \cdot 10^{6} /\left(Q_{\mathrm{nh}} \cdot 1 \cdot 3600\right)
$$

Imbalance of the diesel fuel utilization, $\mathrm{kg} / \mathrm{h}$

$$
\Delta G_{d f}=G_{d f}-\left(G_{e}+G_{T}\right) / 3600
$$


The levels of diesel fuel specific consumption correspond to a high-efficient heat powerstation [32].

3.2 Material balance of the electric power plant.

Material balance is determined by the equity consumptions of fuel, oxidizer and the products of combustion at the input and output of the mini CHP.

Input flow rate $G_{i n}=G_{\text {air }}+G_{\text {air } 1}+G_{d f}$

Output flow rate $G_{e x}=B_{s g}^{*}+G_{a i r}^{*}$

Mass flow rate imbalance $\Delta G=G_{\text {in }}-G_{\text {out }}$

3.3 Heat balance of the electric power plant.

Heat balance is determined by the equity capacity energy flows at the input and output, taking into account the heat loss of the installation.

Input power $Q_{\text {in }}=Q_{\text {low }}^{p} G_{d f} \eta_{\text {chem }}$

Output power $Q_{\text {out }}=Q_{e}+G_{e x} C_{e x} t_{e x}$

Power imbalance $\Delta Q=Q_{\text {in }}-Q_{\text {out }}$

\section{CONCLUSIONS}

The principal possibility for using the products of the motor diesel fuel air conversion for the operation of the SOFC-based electrochemical generator has been demonstrated.

Calculation studies have shown that the heat of combustion of the products of the diesel fuel air conversion (at $\alpha=0.4$ ) is equal to $4872 \mathrm{~kJ} /(\mathrm{kg}$ of synthesis gas), the fuel cell EMF is $0.985 \mathrm{~V}$, the portion of hydrogen oxidized at the anode is 0.894 , the temperature of hydrogen oxidation at the SOFC anode is $780{ }^{\circ} \mathrm{C}$. The results of calculations carried out for the ECG are in reasonable agreement with the literature data obtained for other liquid hydrocarbon fuels.

Comparison with modern power sources has shown that both the specific consumption of diesel fuel for the production of electric power equal to $114 \mathrm{~g} / \mathrm{kWh}(162 \mathrm{~g}$ r.f./kW·h) and heat power equal to $31.7 \mathrm{~kg} / \mathrm{GJ}$ ( $45.1 \mathrm{~kg}$ r.f./GJ, $189 \mathrm{~kg}$ r.f./ Gcal) corresponds to a high-efficient heat power-station and lower than in modern diesel-electric stations of equal power.

It is noted that thermal energy for heating and hot water supply in this cogeneration technology is an additional product that reduces overall consumer costs.

\section{LIST OF ACRONYMS}

- CE - Coefficient of Efficiency

- $\mathrm{SG}$ - Synthesis Gas

- WHB - Waste-Heat Boiler-utilizer

- SOFC - Solid Oxide Fuel Cell

- CHPP - Combined Heat and Power Plant 
- EMF - Electro Motive Force

- ECG - ElectroChemical Generator

- GTP - Gas-Turbine Plant

- STP - Steam-Turbine Plant

\section{ACKNOWLEDGEMENTS}

The article was prepared with the financial support of the Government of the Russian Federation (Contract No 02.A03.21.0006).

\section{REFERENCES}

[1] Lykova, S.A., Highly efficient hybrid power generation systems based on fuel cells. Thermal Engineering, 49(1), pp. 54-60, 2002.

[2] Sgobbi, A., Nijs, W., De Miglio, R., Chiodi, A., Gargiulo, M. \& Thiel, C., How far away is hydrogen? Its role in the medium and long-term decarbonisation of the European energy system. International Journal of Hydrogen Energy, 41(1), pp. 19-35, 2016. https://doi.org/10.1016/j.ijhydene.2015.09.004

[3] Grigor'yants, R.R., Zalkind, V.I., Ivanov, P.P., Lyalin, D.A. \& Miroshnichenko, V.I., Thermodynamic model and analysis of hybrid power installations built around solidoxide fuel cells and gas-turbine units. Thermal Engineering, 55(9), pp. 790-794, 2008. https://doi.org/10.1134/s0040601508090115

[4] Dubinin, A.M., Shcheklein, S.E., Tuponogov, V.G., Ershov, M.I. \& Kagramanov, Y.A., Experimental and theoretical study of the effectiveness of the production of hydrogen by steam conversion of methane using circulating fluidized bed technology. International Journal of Hydrogen Energy, 41(20), pp. 8433-8437, 2016. https://doi.org/10.1016/j. ijhydene.2016.03.163

[5] Dubinin, A.M., Tuponogov, V.G. \& Ikonnikov, I.S., Modeling the process of producing hydrogen from methane. Theoretical Foundations of Chemical Engineering, 47(6), pp. 697-701, 2013. https://doi.org/10.1134/s0040579513050163

[6] Beznosova, D.S., Grigoruk, D.G., Lyalin, D.A. \& Turkin, A.V., Prospects for using hybrid power installations on the basis of solid-oxide fuel cells integrated with intracycle coal gasification. Thermal Engineering, 58(9), pp. 774-778, 2011. https://doi. org/10.1134/s0040601511090035

[7] Dubinin, A.M., Tuponogov, V.G. \& Filippov, D.V., Determining maximum capacity of an autothermal fluidized-bed gas generator. Thermal Engineering, 56(5), pp. 421-425, 2009. https://doi.org/10.1134/s0040601509050115

[8] Shigarov, A.B. \& Kirillov, V.A., Modeling of membrane reactor for steam methane reforming: From granular to structured catalysts. Theoretical Foundations of Chemical Engineering, 46(2), pp. 97-107, 2012. https://doi.org/10.1134/s004057951202011x

[9] Kurganov, V.A., Zeigarnik, Y.A., Maslakova, I.V., Ivanov, F.P. \& Martynov, S.B., Hightemperature heat shielding panels with thermochemical cooling based on the reaction of steam conversion of methane. High temperature, 38(6), pp. 926-937, 2000. https:// doi.org/10.1023/a:1004101709347

[10] Lakhete, P. \& Janardhanan, V.M., Modeling process intensified catalytic plate reactor for synthesis gas production. Chemical Engineering Science, 110, pp. 13-19, 2014. https://doi.org/10.1016/j.ces.2013.05.021

[11] Kurteeva, A.A., Beresnev, S.M., Osinkin, D.A., Kuzin, B.L., Vdovin, G.K., Zhuravlev, V.D., ... \& Yaroslavtsev, I.Y., Single solid-oxide fuel cells with supporting Ni-cermet anode. High Temperature, 47(12), pp. 1381-1388, 2011. https://doi.org/10.1134/ s102319351112007x 
[12] Takeguchi, T., Kani, Y., Yano, T., Kikuchi, R., Eguchi, K., Tsujimoto, K., ... \& Aizawa, M., Study on steam reforming of $\mathrm{CH}_{4}$ and $\mathrm{C}_{2}$ hydrocarbons and carbon deposition on Ni-YSZ cermets. Journal of Power Sources, 112(2), pp. 588-595, 2002. https:// doi.org/10.1016/s0378-7753(02)00471-8

[13] Chen, B., Exergy analysis and $\mathrm{CO}_{2}$ emission evaluation for steam methane reforming. International Journal of Hydrogen Energy, 37(4), pp.3191-3200, 2012.

[14] Yan, Y., Zhang, J. \& Zhang, L., Properties of thermodynamic equilibrium-based methane autothermal reforming to generate hydrogen. International Journal of Hydrogen Energy, 38(35), pp. 15744-15750, 2013. https://doi.org/10.1016/j.ijhydene.2013.06.007

[15] Barona, J., Bulewicz, E.M., Kandefer, S., Pilawska, M., Żukowski, W. \& Hayhurst, A.N., Combustion of hydrogen in a bubbling fluidized bed. Combustion and Flame, 156(5), pp. 975-984, 2009. https://doi.org/10.1016/j.combustflame.2008.11.014

[16] Peters, R., Deja, R., Blum, L., Pennanen, J., Kiviaho, J. \& Hakala, T., Analysis of solidoxide fuel cell system concepts with anode recycling. International Journal of Hydrogen Energy, 38(16), pp. 6809-6820, 2013. https://doi.org/10.1016/j.ijhydene.2013.03.110

[17] Halinen, M., Saarinen, J., Noponen, M., Vinke, I.C. \& Kiviaho, J., Experimental analysis on Performance and Durability of SOFC Demonstration unit. Fuel Cells, 10(3), pp. 440-452, 2010. https://doi.org/10.1002/fuce.200900152

[18] Halinen, M., Thomann O. \& Kiviaho, J., Effect of anode off-gas recycling on reforming of natural gas for solid oxide fuel cell systems. Fuel Cells, 12(5), pp. 754-760, 2012. https://doi.org/10.1002/fuce.201200047

[19] Munts, V.A., Volkova, Y.V., Plotnikov, N.S., Dubinin, A.M., Tuponogov, V.G. \& Chernishev V.A., Studying the characteristics of a $5 \mathrm{~kW}$ power installation on solid-oxide fuel cells with steam reforming of natural gas. Thermal Engineering, 62(11), pp. 779-784, 2015. https://doi.org/10.1134/s004060151511004x

[20] Dubinin, A.M. \& Shcheklein, S.E., Mini coal-fired CHP plant on the basis of synthesis gas generator $\left(\mathrm{CO}+\mathrm{H}_{2}\right)$ and electrochemical current generator. International Journal of Hydrogen Energy, 42(41), pp. 26048-26058, 2017. https://doi.org/10.1016/j. ijhydene.2017.06.190

[21] Dubinin, A.M., Shcheklein, S.E., Tuponogov, V.G. \& Ershov, M.I., Mini CHP based on the electrochemical generator and impeded fluidized bed reactor for methane steam reforming. Alternative Energy and Ecology (ISJAEE), (19-21), pp. 95-105, 2017. https://doi.org/10.15518/isjaee.2017.19-21.095-105

[22] Shcheklein, S.E. \& Dubinin, A.M., Solid wastes (SW) converting into electric and thermal energy using a gasifier and an electrochemical generator. WIT Transactions on Ecology and the Environment, WIT Press. Energy and Sustainability, 224, pp. 451-462, 2017. https://doi.org/10.2495/esus170421

[23] Zhang, X., Chan, S.H., Li, G., Ho, H.K., Li, J. \& Feng, Z., A review of integration strategies for solid oxide fuel cells. Journal of Power Sources, 195(3), pp. 685-702, 2010. https://doi.org/10.1016/j.jpowsour.2009.07.045

[24] Peters, R., Deja, R., Blum, L., Pennanen, J., Kiviaho, J. \& Hakala, T., Analysis of solid oxide fuel cell system concepts with anode recycling. International Journal of Hydrogen Energy, 38(16), pp. 6809-6820, 2013. https://doi.org/10.1016/j.ijhydene.2013.03.110

[25] Internal combustion engines. Theory of reciprocating and combined engines. ed. Orlin, A.S. \& Kruglov, M.G., Moscow, Mashinostroenie, p. 372, 1983.

[26] Korovin, N.A., Fuel Cells and Electrochemical Power Installations, MPEI, Moscow, p. 145, 2005. 
[27] Baskakov, A.P., Dubinin, A.M. \& Tuponogov, V.G., On mechanism of coal steam gasification. Industrial Power Engineering, 4, pp. 40-42, 2008.

[28] Baskakov, A.P. \& Volkova, Y.V., Physicochemical principles of thermal processes. Handbook, Moscow, Teplotekhnik, p. 173, 2013.

[29] Zhao, Y., Sadhukhan, J., Lanzini, A., Brandon, N. \& Shah, N., Optimal integration strategies for a syngas fuelled SOFC and gas turbine hybrid. Journal of Power Sources, 196(22), pp. 9516-9527, 2011. https://doi.org/10.1016/j.jpowsour.2011.07.044

[30] Baskakov, A.P., Volkova, J.V. \& Plotnikov, N.S., Optimum chemical regeneration of the gases burnt in solid oxide fuel cells. Journal of Engineering Physics and Thermophysics, 87(4), pp. 763-778, 2014. https://doi.org/10.1007/s10891-014-1070-9

[31] Bazhenov, M.I., Bogorodsky, A.S., Sazanov, B.V., Yurenev,V.N. \& Sokolov, E.Y., (eds), Industrial Thermal Power Stations, 2nd edn., Moscow, Energy, p. 296, 1979.

[32] Yakovlev, B.V., Improving the Efficiency of Cogeneration and District Heating Systems. Moscow, Heat news, p. 448, 2008. 